Check for updates

Cite this: RSC Adv., 2018, 8, 38935

Received 14th September 2018 Accepted 13th November 2018

DOI: $10.1039 / c 8 r a 07657 j$

rsc.li/rsc-advances

\section{Efficient visible-light full-color tuning of self- organized helical superstructures enabled by fluorinated chiral switches $\dagger$}

\author{
Lang Qin, Wei Gu, Yingying Chen, Jia Wei (iD * and Yanlei Yu iD
}

\section{Introduction}

Cholesteric liquid crystals (CLCs) possessing self-organized helical superstructures ${ }^{1}$ are a class of materials capable of selectively reflecting light according to Bragg's law. Dynamic tuning of reflection wavelength of the CLCs by external stimuli, including heat, ${ }^{2,3}$ electric field, ${ }^{4,5}$ chemical reaction ${ }^{6,7}$ and light ${ }^{8-16}$ is of great significance in many applications, such as color filters, ${ }^{17}$ reflectors, ${ }^{18,19}$ displays, ${ }^{20,21}$ lasers, ${ }^{22,23}$ and sensors. $^{24,25}$ Among all the stimuli, light wields advantages of remote, spatial and temporary controllability, therefore lightdriven CLCs are widely studied..$^{26,27}$

The commonly used method to obtain light-driven CLCs is to dope a small amount of photoresponsive chiral switches into nematic liquid crystals (LCs). ${ }^{28,29}$ The ability of a chiral switch to twist the nematic LC into helical superstructures is represented by the helical twisting power (HTP, $\beta$ ) in the equation: $\beta=1$ / $(p c)$, where $c$ is the concentration of the chiral switch and $p$ is the pitch length of the helical superstructures. The central wavelength of the reflection $\lambda$ is related to the pitch, i.e. defined as $\lambda$ $=n p$, where $n$ is the average refraction index of the LC host. The configurational change of the chiral switches upon light irradiation enables the HTP variation, resulting in the photocontrol of the helices as well as the reflection wavelength.

Department of Materials Science, State Key Laboratory of Molecular Engineering of Polymers, Fudan University, 220 Handan Road, Shanghai 200433, China. E-mail: weijia@fudan.edu.cn

† Electronic supplementary information (ESI) available. See DOI: 10.1039/c8ra07657j
Azobenzene-based chiral switches draw tremendous attention because of the dramatic difference in molecular geometry between the rod-like trans form and bent cis form, leading to large variation in HTP upon photoisomerization. ${ }^{26}$ However, the necessity of high energy UV light to induce the trans-cis isomerization of normal azobenzene ${ }^{30,31}$ impedes their practical applications, since UV light irradiation might bring about material decomposition and damage to biosamples. In this regard, developing photoresponsive CLCs that primarily respond to visible light and near-infrared (NIR) is highly desired for the wide utilizations. ${ }^{12,13}$

Li et al. developed NIR-light-tunable CLCs loaded with azobenzene-based chiral switches and upconversion nanoparticles (UCNPs). The UCNPs successfully converted NIR light of different power density to UV light or visible light, which triggered the trans-cis and cis-trans isomerization of the chiral switches respectively and realized the reversible tuning of the reflection wavelength in visible spectrum. ${ }^{13}$ However, energy transfer from the UCNPs to the chiral switches resulted in low photoisomerization efficiency and slow response in this system. It is more straightforward to design novel chiral switches, whose photoisomerization in two directions can be induced by visible light. Recently, Li et al. designed and synthesized a special kind of azobenzene-based chiral switches possessing long conjugated structure. The reversible tuning of reflection colors from the doped CLCs was achieved by visible-light-driven photoisomerization. ${ }^{\mathbf{1 2}}$

It has been proved that azobenzenes with ortho-fluorine atoms have lower energy of the $n$-orbital of the cis isomer, giving rise to a separation of $n-\pi^{*}$ absorption bands of the trans and cis isomers. $^{32,33}$ Green and blue light can therefore be used to 
induce the trans-cis and cis-trans isomerization, respectively. This inspired us to design chiral switches based on fluoroazobenzene to realize visible-light tuning of helical superstructures of the CLC. One should emphasize that Katsonis et al. recently have synthesized fluorinated chiral switches, but they have not reported the visible-light-driven photoisomerization and still used UV light to trigger the trans-cis process. ${ }^{34}$ Herein, we reported the synthesis of axially chiral binaphthyl azobenzenes containing fluorine atoms ortho to azo moieties, which were proved to exhibit reversible visible-lightdriven photoisomerization both in organic solvent and LC media (Fig. 1a). Furthermore, the chiral switches all exhibited high HTP values and only a small amount of the chiral switches successfully induced the formation of the helical superstructures. The CLCs formed by doping the chiral switches into nematic LC E7 generated the full-color dynamical change of the reflection driven by visible light with different wavelengths.

\section{Results and discussion}

\section{Synthesis and characterization}

The visible-light-driven chiral switches were prepared in a facile synthesis route (Fig. 1a and Experimental section Fig. 6), in which the 1,1'-binaphthyl group provides axial chirality and fluoroazobenzene moiety offers the distinct optical properties. Besides, the introduction of two mesogenic rod-like biphenyl enhances the solubility in commercially available nematic LC hosts including E7 and 5CB. The chemical structures of chiral switches were identified by ${ }^{1} \mathrm{H},{ }^{19} \mathrm{~F}$ and ${ }^{13} \mathrm{C}$ NMR spectroscopy.

\section{Visible-light-driven photoisomerization}

UV-vis spectra were recorded to make clear the changes of the absorption of the chiral switches before and after sequential visible light irradiation at $530 \mathrm{~nm}$ and $445 \mathrm{~nm}$. A solution of S-1-
5 in chloroform was placed in dark to maximize the absorption at $342 \mathrm{~nm}$ which corresponds to the $\pi-\pi^{*}$ absorption band of trans o-fluorinated azobenzene. As shown in Fig. 1b, $530 \mathrm{~nm}$ light irradiation triggered trans-cis isomerization evidenced by the intensity decrease of $\pi-\pi^{*}$ absorption band. In the visible part of the spectra $(420-490 \mathrm{~nm})$, two isobestic points at $428 \mathrm{~nm}$ and $464 \mathrm{~nm}$ were found due to the separation of $\mathrm{n}-\pi^{*}$ absorption bands of the two isomers (Fig. 1c). The $n-\pi^{*}$ absorption band of cis isomer (450 nm) appeared with a slight blue-shift compared to that of trans isomer (468 nm), which is different from the parent azobenzenes without the substitution of electron-withdrawing fluorine atoms. The solution of S-1-5 in chloroform took about $140 \mathrm{~s}$ to reach photostationary state (PSS) upon $530 \mathrm{~nm}$ light irradiation, whereas its reverse process took about $190 \mathrm{~s}$ to reach $\mathrm{PSS}_{445}$ by $445 \mathrm{~nm}$ light irradiation (Fig. 1d). Similar phenomena were also found in the other two chiral switches (Fig. S1 and S2, ESI $\dagger$ ). These results indicate that both the trans-cis and cis-trans isomerization of the newly designed chiral switches can be fully triggered by visible light in solvent.

\section{Measurement of HTP}

Encouraged by the reversible visible-light-driven photoisomerization of the chiral switches in organic solvent, we doped the chiral switches into the commercially available nematic LC host to evaluate their HTP variation upon visible light irradiation. As shown in Fig. 2a and S3, ESI $\dagger$, a small amount of the chiral switches $(0.4 \mathrm{wt} \%$ in E7) successfully induced the formation of CLC phase, which was testified by the characteristic fingerprint textures observed by polarized optical microscope (POM), indicating that the chiral switches all have high HTP. The screw senses of the CLCs doped with the chiral switches were all determined to be left-handed according to the miscibility tests (Fig. S4, ESI $\dagger$ ). The HTP values of the chiral

(a)

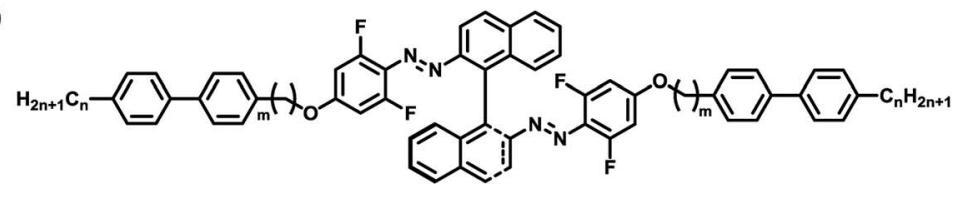

S-3-5 $m=3, n=5 ; S-1-3 m=1, n=3 ; S-1-5 m=1, n=5$

(b)

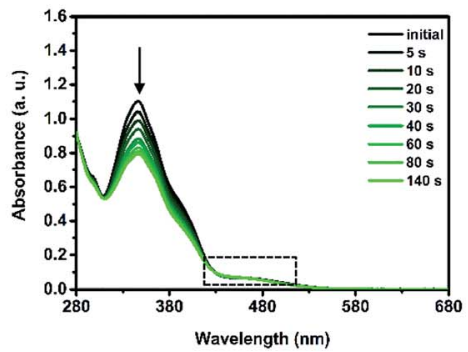

(c)

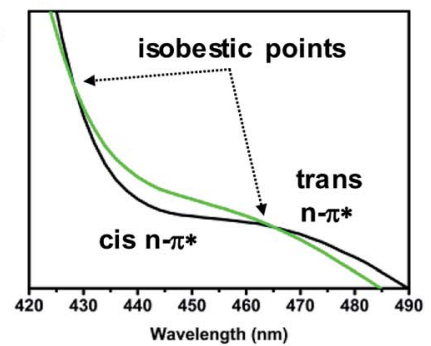

(d)

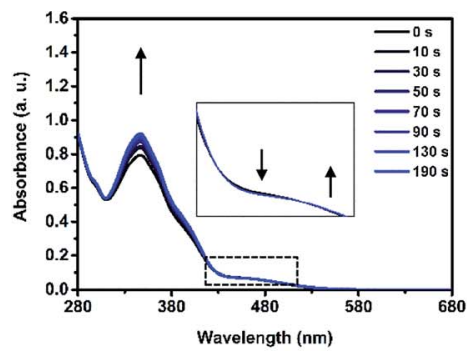

Fig. 1 (a) Chemical structure of the chiral switches studied in the experiment. (b) Changes of UV-vis absorption spectra of S-1-5 in chloroform (2 $\times 10^{-5} \mathrm{M}$ ) upon irradiation of $530 \mathrm{~nm}$ light $\left(27 \mathrm{~mW} \mathrm{~cm}{ }^{-2}\right)$ from the initial state to the PSS 530 . (c) Partial UV-vis absorption spectra of S-1-5 between 420-490 nm showing the separation of $n-\pi^{*}$ bands of trans and cis isomers. (d) Changes of UV-vis absorption spectra of S-1-5 in chloroform $\left(2 \times 10^{-5} \mathrm{M}\right)$ upon irradiation of $445 \mathrm{~nm}$ light $\left(0.4 \mathrm{~mW} \mathrm{~cm}^{-2}\right)$ from the $\mathrm{PSS}_{530}$ to the $\mathrm{PSS}_{445}$. 
(a)

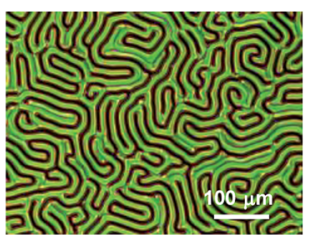

(b)

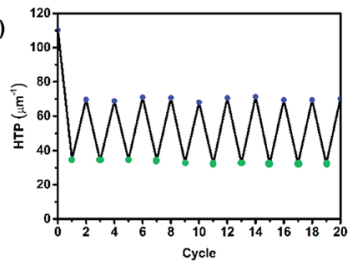

(c)

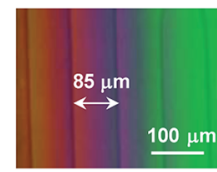

Initial state

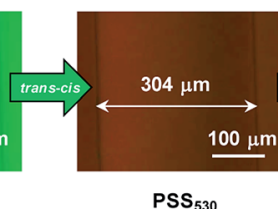

PSS $_{530}$

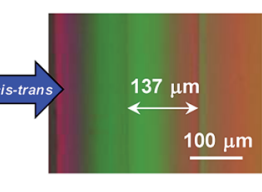

PSS $_{445}$

Fig. 2 (a) Fingerprint textures of 0.4 wt\% S-1-5 in E7 observed through POM. Scale bar, $100 \mu \mathrm{m}$. (b) Cycles of the changes of HTP of $1.0 \mathrm{wt} \% \mathrm{~S}-$ 1-5 in E7 upon alternate irradiation with $530 \mathrm{~nm}$ and $445 \mathrm{~nm}$ light. (c) POM images showing the distance changes of disclination lines of 1.0 wt\% S-1-5 in achiral LC E7 in the wedge cell before (left) and after sequential visible light irradiation at $530 \mathrm{~nm}$ (middle) and $445 \mathrm{~nm}$ (right).

switches were measured according to Grandjean-Cano method $^{35}$ (Fig. S5, ESI $\dagger$ ). Taking the mixture of $1.0 \mathrm{wt} \%$ S-1-5 in E7 as an example (Fig. 2c), the distance between disclination lines gradually increased from 85 to $304 \mu \mathrm{m}$ and finally became stable at PSS $_{530}$ thanks to the trans-cis isomerization of S-1-5. The resultant percent change in $\beta$ was calculated as $72.4 \%$. Reverse process occurred when irradiated with $445 \mathrm{~nm}$ light. The excellent fatigue resistance was confirmed by repeated irradiation of $530 \mathrm{~nm}$ and $445 \mathrm{~nm}$ light after many cycles and no obvious degradation was observed (Fig. $2 \mathrm{~b}$ and S8, ESI $\dagger$ ). Therefore, the reversible tuning of S-1-5 was achieved only by visible light irradiation in LC media, which successfully induced the change of the helical superstructures. S-3-5 and S-15 also showed similar properties in CLC manipulation (Fig. S68, ESI†े).

The HTP values of three chiral switches are summarized in Table 1. Compared to the previously reported visible-lightdriven chiral switches,${ }^{12}$ these chiral switches all have higher HTP value at the initial state and more significant change of HTP upon light irradiation. The HTPs of S-3-5 and S-1-5 in 5CB are higher than that in E7, while $\mathbf{S - 1 - 3}$ shows higher HTP value in E7 than in 5CB. The higher HTP of S-3-5 and S-1-5 in 5CB may

Table 1 Helical twisting power $\beta\left(\mu \mathrm{m}^{-1}\right.$, mol\%) of the chiral switches in different nematic LC hosts at different states

\begin{tabular}{lllllrl}
\hline & & \multicolumn{2}{l}{$\beta\left(\mu \mathrm{m}^{-1}, \mathrm{~mol} \%\right)$} & & \\
\cline { 3 - 5 } Sample & Host & Initial & PSS $_{530}$ & PSS $_{445}$ & $\Delta \beta^{a}$ & $\Delta \beta / \beta_{\text {ini }}{ }^{b}(\%)$ \\
\hline S-3-5 & E7 & 100 & 28 & 59 & 72 & 72.4 \\
& 5CB & 133 & 34 & 80 & 99 & 74.5 \\
S-1-3 & E7 & 152 & 39 & 78 & 113 & 74.5 \\
& 5CB & 143 & 33 & 67 & 110 & 76.9 \\
S-1-5 & E7 & 110 & 32 & 69 & 78 & 70.6 \\
& 5CB & 146 & 29 & 68 & 117 & 80.3
\end{tabular}

${ }^{a}$ Decrease. ${ }^{b}$ Percent change in $\beta$ from the initial state to the $\mathrm{PSS}_{530}$.

arise from the higher degree of similarity between the end groups of chiral switches and 5CB host. Different LC hosts result in different intermolecular association between the chiral switches and the host. Therefore, we could conclude that subtle dependence of HTP exists on the molecular structures of both the dopant and the nematic LC host, which is consistent with previously reported results. ${ }^{29}$ Moreover, HTP values of these chiral switches exhibit remarkable differences among various PSSs induced by visible light, which indicates reversible visiblelight-tunable property of the chiral switches.

\section{Phototunable reflection}

The high HTP value and the considerable difference among various states of the chiral switches allowed us to tune the reflection color of the CLC reversibly by visible light. Although $\mathbf{S}$ 1-3 has higher HTP, the poor solubility in LC host (less than $10 \mathrm{wt} \%$ ) indicates that it is not an ideal candidate for CLC manipulation. The HTP variation of S-1-5 between PSS $_{530}$ and $\mathrm{PSS}_{445}$ is larger than that of S-3-5. Therefore, S-1-5 was chosen to demonstrate efficient tuning of the reflection color in CLC upon visible light irradiation. A mixture of $15.8 \mathrm{wt} \%$ S-1-5 in achiral nematic LC E7 was filled into a $5 \mu \mathrm{m}$ thick planar aligned cell via capillary force. Successfully, the CLC mixture exhibited reversible tuning of reflection color across the entire visible spectrum. At the initial state, the reflection band was located in the UV region $(<400 \mathrm{~nm})$. When irradiated with $530 \mathrm{~nm}$ light for 7 seconds, the cell appeared to be blue and the central reflection wavelength was shifted to around $440 \mathrm{~nm}$. As shown in Fig. 3a and $\mathrm{c}$, the reflection band red-shifted over the entire visible light region and the reflection color dynamically changed from blue via green to dark red upon continual $530 \mathrm{~nm}$ light irradiation within $27 \mathrm{~s}$. The reverse process happened upon $445 \mathrm{~nm}$ light irradiation (Fig. $3 \mathrm{~b}$ and d). Fig. 4 shows the real cell images of the CLC mixture in primary blue, green, red (RGB) reflection colors tuned by $530 \mathrm{~nm}$ and $445 \mathrm{~nm}$ light. Interestingly, a green and red "CLC" pattern in blue background was created by photomask technology. Therefore, reversible tuning of the reflection color and erasable patterning process of the CLC mixture were achieved in the visible spectrum, which is of significance in the practical display applications. These rewritable materials are expected to replace paper and lay the foundation for the realization of inkless printing technology. Besides, the reflection wavelength of the cell can be extended to NIR region $(1175 \mathrm{~nm})$ under irradiation of $530 \mathrm{~nm}$ light as expected. In the previously reported visible-light-driven CLC, high doping concentration of $22.7 \mathrm{wt} \%$ was needed to induce helical superstructures exhibiting dynamic reflection colors, which may narrow the temperature range of LC phase and increase viscosity of the CLC. ${ }^{36}$ Here, the new types of visible-light-driven chiral switches possess high HTP value, which can efficiently induce and tune helical superstructures with low doping concentration.

\section{Thermal relaxation}

As is well-known, the application of light-directed RGB reflection colors change in CLCs doped with azo-based chiral 
(a)

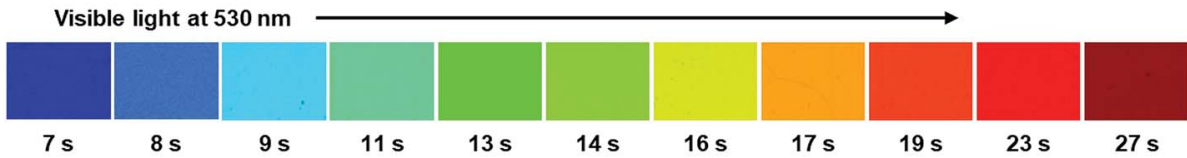

(b)

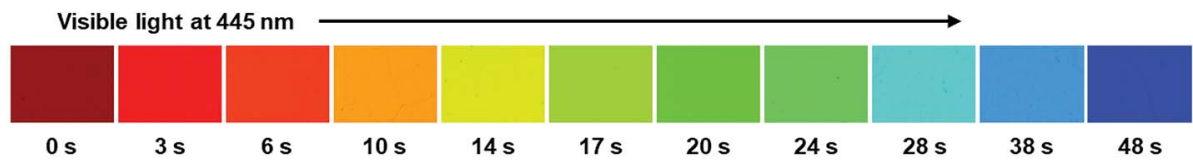

(c)

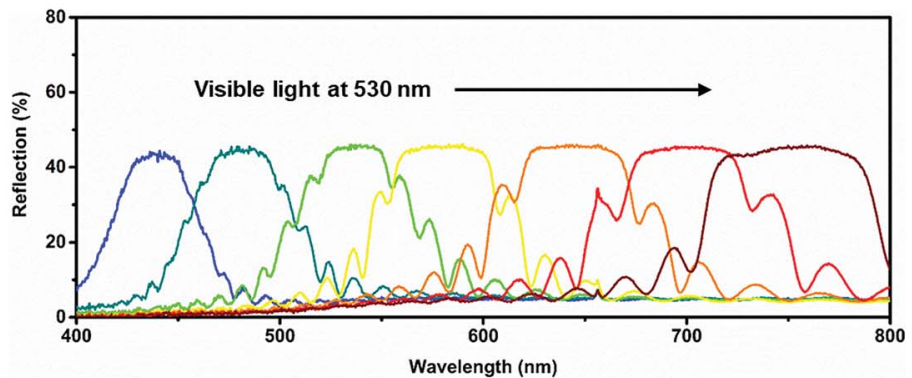

(d)

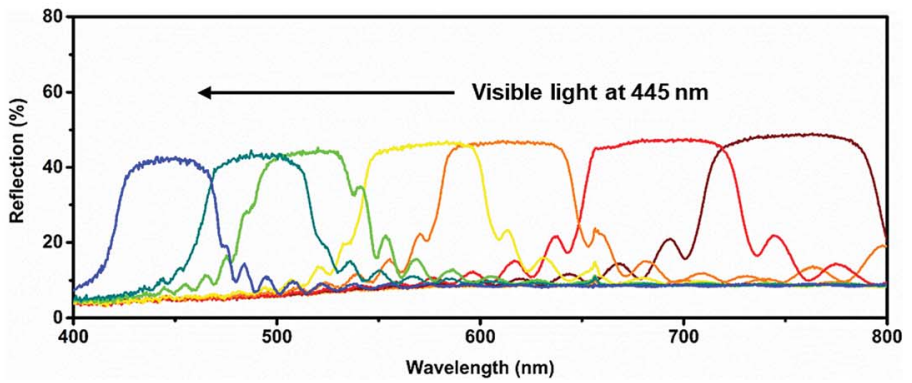

Fig. 3 Reflection color images of the CLC mixture in a $5 \mu \mathrm{m}$ planar cell with $15.8 \mathrm{wt} \% \mathrm{~S}-1-5$ in E7 (a) upon consecutive visible light irradiation at $530 \mathrm{~nm}\left(15 \mathrm{~mW} \mathrm{~cm}^{-2}\right)$ and (b) $445 \mathrm{~nm}\left(0.4 \mathrm{~mW} \mathrm{~cm}^{-2}\right)$. Reflective spectra of the CLC mixture doped with 15.8 wt\% S-1-5 in E7 upon consecutive visible light irradiation at (c) $530 \mathrm{~nm}\left(15 \mathrm{~mW} \mathrm{~cm}^{-2}\right)$ and (d) $445 \mathrm{~nm}\left(0.4 \mathrm{~mW} \mathrm{~cm}^{-2}\right)$.
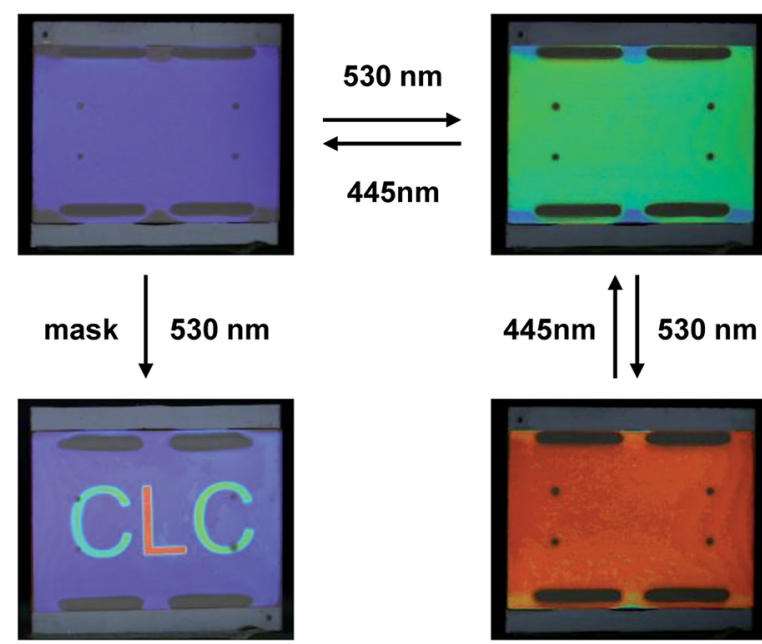

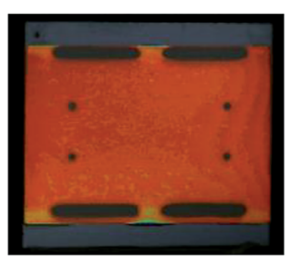

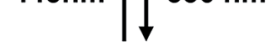

Fig. 4 Real cell images of CLC mixture in a $5 \mu \mathrm{m}$ planar cell $(2.0 \mathrm{~cm} \times$ $2.5 \mathrm{~cm}$ ) with 15.8 wt\% S-1-5 in E7 upon irradiation of visible light showing primary RGB colors and "CLC" pattern.

switches was limited because of the competing thermal back relaxation (cis-trans isomerization in darkness), which results in the lack of stability. ${ }^{\mathbf{1 1}}$ It's worth noting here that the thermal relaxation process of the reflection wavelength took about 50 hours through the entire visible region (Fig. 5), illustrating that our CLCs exhibit excellent thermal stability compared to that with common azo-based chiral switches without fluorine atoms, which is 10 hours. $^{37}$ The substitution of electron-withdrawing fluorine atoms may stabilize the cis isomers of the chiral switches and therefore lead to the excellent thermal stability of the CLCs. ${ }^{29,34}$ Better thermal stability of our newly designed chiral switches results in color stabilities of the reflecting displays, which is of great importance in practical applications.

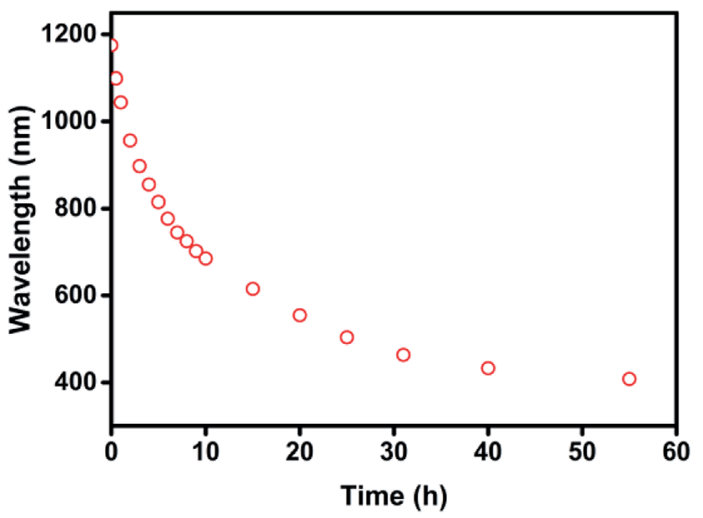

Fig. 5 Thermal back process of central reflection wavelength of 15.8 wt\% S-1-5 in E7 from the PSS 530 at room temperature $\left(25^{\circ} \mathrm{C}\right)$. 


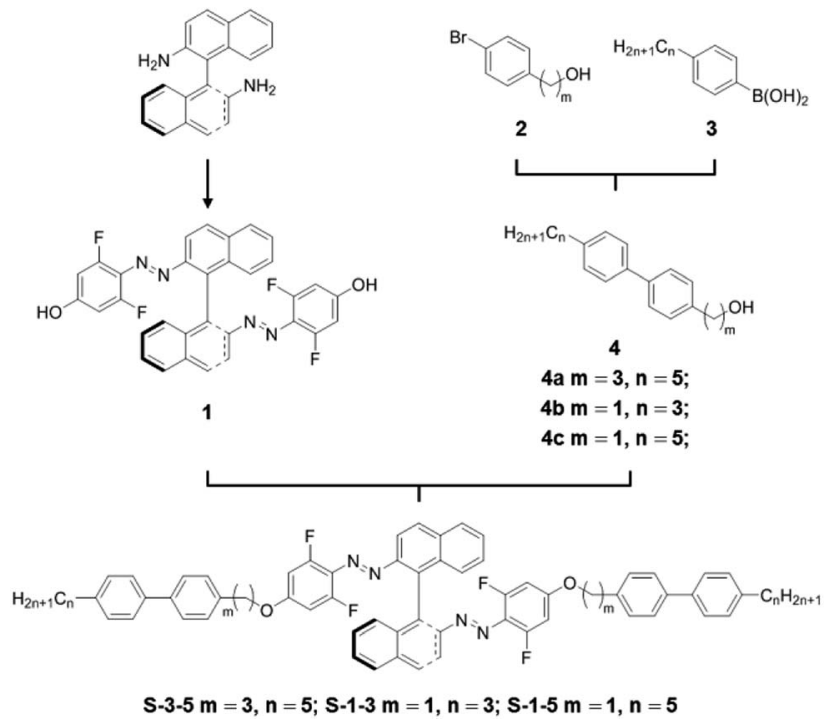

Fig. 6 Synthesis of visible-light-driven chiral switches.

\section{Conclusions}

In conclusion, we have designed a series of visible-light-driven chiral switches based on $o$-fluorinated azobenzene. The substitution of four fluorine atoms endows chiral switches with visible-light-driven two-way photoisomerization, and makes cis isomers more thermally stable at the same time. A small amount of S-1-5 is able to efficiently induce self-organized helical superstructures in the CLC, whose reflection color is capable of being reversibly tuned in full-range visible spectrum. The investigation of these intriguing materials would assist full exploration of different potential applications of the CLCs, in which high energy UV light is unfavourable.

\section{Experimental}

\section{Materials and methods}

All chemicals and solvents were purchased from commercial suppliers and used without further purification. ${ }^{1} \mathrm{H}$ NMR, ${ }^{13} \mathrm{C}$ NMR and ${ }^{19} \mathrm{~F}$ NMR spectra were recorded in $\mathrm{CDCl}_{3}$. Chemical shifts are in $\delta$ units (ppm) with the residual solvent peak as the internal standard. The coupling constant $(J)$ is reported in hertz $(\mathrm{Hz})$. NMR splitting patterns are designed as follows: s, singlet; $\mathrm{d}$, doublet; $\mathrm{t}$, triplet; and $\mathrm{m}$, multiplet. UV-vis spectrum was taken by a Perkin Elmer Lambda 650 Spectrometer. Textures, contact areas, reflection colors and distance changes of disclination lines were observed by a Leika DM2500p polarizing optical microscopy (POM). $530 \mathrm{~nm}$ light irradiation was carried out by a CCS HLV-24GR-3W LED light source. $445 \mathrm{~nm}$ light irradiation was carried out by a JD BL-445-300 laser light source. Reflection spectra of CLCs were examined with an Ideaoptica spectrometer.

\section{Synthesis of chiral switches}

Synthesis of intermediate 1. $(S)-(-)-1,1^{\prime}$-Binaphthyl-2,2' diamine $(0.48 \mathrm{~g}, 1.7 \mathrm{mmol})$ was dissolved in a solution of $\mathrm{H}_{2} \mathrm{O}(9$
$\mathrm{mL})$ and concentrated $\mathrm{HCl}(1.3 \mathrm{~mL})$. The solution was cooled to $0{ }^{\circ} \mathrm{C}$ with ice water bath. A solution of sodium nitrite $(0.29 \mathrm{~g}, 4.2$ $\mathrm{mmol})$ in $\mathrm{H}_{2} \mathrm{O}(10 \mathrm{~mL})$ was added dropwise with stirring. The solution of 3,5-difluorophenol ( $0.50 \mathrm{~g}, 3.87 \mathrm{mmol})$ and $\mathrm{NaOH}$ $(0.45 \mathrm{~g}, 11.3 \mathrm{mmol})$ in $\mathrm{H}_{2} \mathrm{O}(15 \mathrm{~mL})$ was dropped into the resulting brown yellow suspension. The suspension was acidified with aqueous $\mathrm{HCl}$ and filtered. The precipitate was washed with $\mathrm{H}_{2} \mathrm{O}$ and dried to get the crude product, which was purified by chromatography on silica gel with dichloromethane/ethyl acetate $(19: 1)$ to give a red brown solid $(0.25 \mathrm{~g}, 26 \%) .{ }^{1} \mathrm{H}$ NMR (500 MHz, $\left.\mathrm{CDCl}_{3}\right) \delta=8.19-8.05(\mathrm{~m}, 4 \mathrm{H}), 7.98(\mathrm{~d}, J=$ $8.2 \mathrm{~Hz}, 2 \mathrm{H}), 7.51(\mathrm{t}, J=7.2 \mathrm{~Hz}, 2 \mathrm{H}), 7.34-7.21(\mathrm{~m}, 4 \mathrm{H}), 6.17(\mathrm{~d}, J$ $=12.8 \mathrm{~Hz}, 4 \mathrm{H})$.

General procedure for the synthesis of intermediate 4 . To a magnetically stirred mixture of $2(1.0 \mathrm{mmol})$ and $3(1.4 \mathrm{mmol})$ in toluene $(20 \mathrm{~mL})$ at ambient temperature under Ar atmosphere was added a solution of potassium carbonate $(4.0 \mathrm{mmol})$ in $\mathrm{H}_{2} \mathrm{O}(10 \mathrm{~mL})$. A small amount of methyltrioctylammonium chloride and $\mathrm{Pd}\left(\mathrm{PPh}_{3}\right)_{4}$ were added to the solution. The reaction mixture was then slowly heated to reflux for $12 \mathrm{~h}$ and cooled to ambient temperature. The solvents were removed under reduced pressure. The crude product was purified by chromatography on silica gel with dichloromethane to give the white pure product.

4a. White solid, $89 \%$ yield. ${ }^{1} \mathrm{H}$ NMR $\left(400 \mathrm{MHz}, \mathrm{CDCl}_{3}\right) \delta=$ $7.50(\mathrm{dd}, J=8.2,6.6 \mathrm{~Hz}, 4 \mathrm{H}), 7.25(\mathrm{t}, J=8.2 \mathrm{~Hz}, 4 \mathrm{H}), 3.71(\mathrm{t}, J=$ $6.4 \mathrm{~Hz}, 2 \mathrm{H}), 2.75(\mathrm{t}, J=7.8 \mathrm{~Hz}, 2 \mathrm{H}), 2.63(\mathrm{t}, J=7.8 \mathrm{~Hz}, 2 \mathrm{H}), 1.98-$ $1.89(\mathrm{~m}, 2 \mathrm{H}), 1.70-1.60(\mathrm{~m}, 2 \mathrm{H}), 1.42-1.31(\mathrm{~m}, 2 \mathrm{H}), 0.90(\mathrm{t}, J=$ $7.0 \mathrm{~Hz}, 3 \mathrm{H}) .{ }^{13} \mathrm{C} \mathrm{NMR}\left(126 \mathrm{MHz}, \mathrm{CDCl}_{3}\right) \delta=141.89,140.57$, $138.84,138.35,128.80,126.99,126.82,62.34,35.59,34.23$, 31.72, 31.59, 31.21, 22.59, 14.07 .

4b. White solid, 90\% yield. ${ }^{1} \mathrm{H}$ NMR (500 $\left.\mathrm{MHz}, \mathrm{CDCl}_{3}\right) \delta=$ $7.58(\mathrm{~d}, J=8.2 \mathrm{~Hz}, 2 \mathrm{H}), 7.51(\mathrm{~d}, J=8.2 \mathrm{~Hz}, 2 \mathrm{H}), 7.42(\mathrm{~d}, J=$ $8.0 \mathrm{~Hz}, 2 \mathrm{H}), 7.25(\mathrm{~d}, J=8.1 \mathrm{~Hz}, 2 \mathrm{H}), 4.73(\mathrm{~s}, 2 \mathrm{H}), 2.63(\mathrm{t}, J=$ $7.8 \mathrm{~Hz}, 2 \mathrm{H}), 1.72-1.66(\mathrm{~m}, 2 \mathrm{H}), 0.98(\mathrm{t}, J=7.3 \mathrm{~Hz}, 3 \mathrm{H}) .{ }^{13} \mathrm{C} \mathrm{NMR}$ $\left(500 \mathrm{MHz}, \mathrm{CDCl}_{3}\right) \delta=141.97,140.65,139.55,138.16,127.46$, 127.17, 126.91, 65.19, 37.71, 24.58, 13.91.

4c. White solid, 96\% yield. ${ }^{1} \mathrm{H}$ NMR $\left(500 \mathrm{MHz}^{\left.-\mathrm{CDCl}_{3}\right)} \delta=\right.$ 7.59 (d, $J=8.2 \mathrm{~Hz}, 2 \mathrm{H}), 7.51(\mathrm{~d}, J=8.1 \mathrm{~Hz}, 2 \mathrm{H}), 7.43$ (d, $J=$ $8.4 \mathrm{~Hz}, 2 \mathrm{H}), 7.26(\mathrm{~d}, J=8.0 \mathrm{~Hz}, 2 \mathrm{H}), 4.74(\mathrm{~s}, 2 \mathrm{H}), 2.64(\mathrm{t}, J=$ $7.8 \mathrm{~Hz}, 2 \mathrm{H}), 1.69-1.62(\mathrm{~m}, 2 \mathrm{H}), 1.39-1.33(\mathrm{~m}, 4 \mathrm{H}), 0.90(\mathrm{t}, J=$ $6.8 \mathrm{~Hz}, 3 \mathrm{H}) .{ }^{13} \mathrm{C} \mathrm{NMR}\left(500 \mathrm{MHz}, \mathrm{CDCl}_{3}\right) \delta=142.20,140.62$, $139.57,138.12$, 128.84, 127.43, 127.13, 126.90, 65.14, 35.59, $31.57,31.16,22.56,14.03$.

General procedure for the synthesis of S-m-n. To a magnetically stirred solution $1(1.0 \mathrm{mmol})$ and $\mathrm{PPh}_{3}(3.0 \mathrm{mmol})$ in anhydrous THF $(20 \mathrm{~mL})$ at ambient temperature under $\mathrm{Ar}$ atmosphere was added dropwise a mixture of $4(2.5 \mathrm{mmol})$ and diethyl azodicarboxylate $(3.0 \mathrm{mmol})$ in THF $(10 \mathrm{~mL})$. The reaction mixture was then slowly warmed to reflux for $12 \mathrm{~h}$ and cooled to ambient temperature. The solvents were removed under reduced pressure. The crude product was purified by chromatography on silica gel with dichloromethane/petroleum ether $(2: 3)$ to give the orange product.

$\boldsymbol{S}$-3-5. Orange solid, $60 \%$ yield. ${ }^{1} \mathrm{H} \mathrm{NMR}\left(400 \mathrm{MHz}, \mathrm{CDCl}_{3}\right) \delta=$ $8.11(\mathrm{~d}, J=9.0 \mathrm{~Hz}, 2 \mathrm{H}), 8.04-7.91(\mathrm{~m}, 4 \mathrm{H}), 7.56-7.40(\mathrm{~m}, 12 \mathrm{H})$, 7.31-7.17 (m, 10H), 6.31 (d, $J=10.6 \mathrm{~Hz}, 4 \mathrm{H}), 3.86(\mathrm{t}, J=6.3 \mathrm{~Hz}$, 
2H), $2.76(\mathrm{t}, J=7.5 \mathrm{~Hz}, 4 \mathrm{H}), 2.67-2.58(\mathrm{~m}, 4 \mathrm{H}), 2.10-2.01(\mathrm{~m}$, $4 \mathrm{H}), 1.69-1.60(\mathrm{~m}, 4 \mathrm{H}), 1.39-1.31(\mathrm{~m}, 8 \mathrm{H}), 0.91(\mathrm{t}, J=6.8 \mathrm{~Hz}$, $6 \mathrm{H}) .{ }^{13} \mathrm{C} \mathrm{NMR}\left(126 \mathrm{MHz}, \mathrm{CDCl}_{3}\right) \delta=160.38,158.28,158.22$, 156.20, 156.15, 149.57, 141.93, 139.63, 139.06, 138.24, 137.89, $134.63,134.20,128.87,128.78,128.03,127.97,127.18,127.04$, 126.80, 126.50, 113.56, 99.05, 98.84, 67.65, 35.58, 31.57, 31.50, 31.16, 30.29, 22.56, 14.03. ${ }^{19} \mathrm{~F}$ NMR $\left(400 \mathrm{MHz}, \mathrm{CDCl}_{3}\right) \delta=$ -118.05. Mp: $63{ }^{\circ} \mathrm{C}$; MS (ESI): $(\mathrm{M}+\mathrm{H})^{+}$1095.51, found 1095.51.

$\boldsymbol{S}$-1-3. Orange solid, $55 \%$ yield. ${ }^{1} \mathrm{H}$ NMR $\left(500 \mathrm{MHz}, \mathrm{CDCl}_{3}\right) \delta=$ $8.11(\mathrm{~d}, J=9.0 \mathrm{~Hz}, 2 \mathrm{H}), 7.98(\mathrm{dd}, J=25.8,8.5 \mathrm{~Hz}, 4 \mathrm{H}), 7.57$ (d, $J$ $=8.3 \mathrm{~Hz}, 4 \mathrm{H}), 7.53-7.35(\mathrm{~m}, 12 \mathrm{H}), 7.31-7.23(\mathrm{~m}, 6 \mathrm{H}), 6.41(\mathrm{~d}, J=$ $10.4 \mathrm{~Hz}, 4 \mathrm{H}), 4.98(\mathrm{~s}, 4 \mathrm{H}), 2.62(\mathrm{t}, J=7.6 \mathrm{~Hz}, 4 \mathrm{H}), 1.73-1.62(\mathrm{~m}$, $4 \mathrm{H}), 0.97(\mathrm{t}, J=7.3 \mathrm{~Hz}, 6 \mathrm{H}) .{ }^{19} \mathrm{~F}$ NMR $\left(400 \mathrm{MHz}, \mathrm{CDCl}_{3}\right) \delta=$ -117.87. Mp: $85^{\circ} \mathrm{C}$; MS (ESI): $(\mathrm{M}+\mathrm{H})^{+}$983.39, found 983.39.

$\boldsymbol{S}$-1-5. Orange soild, $60 \%$ yield. ${ }^{1} \mathrm{H}$ NMR $\left(400 \mathrm{MHz}, \mathrm{CDCl}_{3}\right) \delta=$ $8.11(\mathrm{~d}, J=9.0 \mathrm{~Hz}, 2 \mathrm{H}), 8.04-7.90(\mathrm{~m}, 4 \mathrm{H}), 7.56(\mathrm{~d}, J=8.2 \mathrm{~Hz}$, $4 \mathrm{H}), 7.53-7.41(\mathrm{~m}, 8 \mathrm{H}), 7.37(\mathrm{~d}, J=8.3 \mathrm{~Hz}, 4 \mathrm{H}), 7.31-7.21(\mathrm{~m}$, $6 \mathrm{H}), 6.40(\mathrm{~d}, J=10.4 \mathrm{~Hz}, 4 \mathrm{H}), 4.98(\mathrm{~s}, 4 \mathrm{H}), 2.63(\mathrm{t}, J=15.6 \mathrm{~Hz}$, $4 \mathrm{H}), 1.65(\mathrm{~m}, 4 \mathrm{H}), 1.38-1.32(\mathrm{~m}, 8 \mathrm{H}), 0.90(\mathrm{t}, J=14.0 \mathrm{~Hz}, 6 \mathrm{H})$. ${ }^{13} \mathrm{C}$ NMR $\left(126 \mathrm{MHz}, \mathrm{CDCl}_{3}\right) \delta=160.01,158.23,158.17,156.15$, 156.09, 149.58, 142.40, 141.40, 137.95, 137.85, 134.66, 134.17, $134.03,128.90,128.86,128.05,127.97,127.89,127.28,127.23$, 126.94, 126.53, 113.55, 99.49, 99.28, 70.47, 35.58, 31.55, 31.14, 22.55, 14.02. ${ }^{19} \mathrm{~F} \mathrm{NMR}\left(400 \mathrm{MHz}, \mathrm{CDCl}_{3}\right) \delta=-117.86 . \mathrm{Mp}: 72{ }^{\circ} \mathrm{C}$; MS (ESI): $(\mathrm{M}+\mathrm{H})^{+}$1039.45, found 1039.45.

\section{Conflicts of interest}

There are no conflicts to declare.

\section{Acknowledgements}

This work is financially supported by the National Natural Science Foundation of China $(51573029,21734003)$, National Key R\&D Program of China (2017YFA0701302), Natural Science Foundation of Shanghai (No.17ZR1440100) and Innovation Program of Shanghai Municipal Education Commission (Grant No. 2017-01-07-00-07-E00027).

\section{Notes and references}

1 H. K. Bisoyi and Q. Li, Angew. Chem., Int. Ed., 2016, 55, 2994.

2 D. J. D. Davies, A. R. Vaccaro, S. M. Morris, N. Herzer, A. P. H. J. Schenning and C. W. M Bastiaansen, Adv. Funct. Mater., 2013, 23, 2723.

3 K. Masuki, A. Takuya, S. Natsuki and W. Tatsuo, Chem. Mater., 2009, 21, 564.

4 J. Xiang, Y. N. Li, Q. Li, D. A. Paterson, J. M. D. Storey, C. T. Imrie and O. D. Lavrentovich, Adv. Mater., 2015, 27, 3014 .

5 C. A. Bailey, V. P. Tondiglia, L. V. Natarajan, M. M. Duning, R. L. Bricker, R. L. Sutherland, T. J. White, M. F. Durstock and T. J. Bunning, J. Appl. Phys., 2010, 107, 013105.

6 A. Saha, Y. Tanaka, Y. Han, C. M. W. Bastiaansen, D. J. Broer and R. P. Sijbesma, Chem. Commun., 2012, 48, 4579.

7 Y. Han, K. Pacheco, C. W. M. Bastiaansen, D. J. Broer and R. P. Sijbesma, J. Am. Chem. Soc., 2010, 132, 2961.
8 T. J. White, M. E. McConney and T. J. Bunning, J. Mater. Chem., 2010, 20, 9832.

9 Q. Li, Y. Li, J. Ma, D.-K. Yang, T. J. White and T. J. Bunning, Adv. Mater., 2011, 23, 5069.

10 M. Mathews and N. Tamaoki, J. Am. Chem. Soc., 2008, 130, 11409.

11 Y. Li, A. Urbas and Q. Li, J. Am. Chem. Soc., 2012, 134, 9573.

12 Y. Wang, A. Urbas and Q. Li, J. Am. Chem. Soc., 2012, 134, 3342.

13 L. Wang, H. Dong, Y. Li, C. Xue, L.-D. Sun, C.-H. Yan and Q. Li, J. Am. Chem. Soc., 2014, 136, 4480.

14 Y. Kim and N. Tamaoki, J. Mater. Chem. C, 2014, 2, 9258.

15 S. Kurihara, S. Nomiyama and T. Nonaka, Chem. Mater., 2001, 13, 1992.

16 Q. Li, L. F. Li, J. Kim, H.-S. Park and J. Williams, Chem. Mater., 2005, 17, 6018.

17 J. Lub, P. van de Witte, C. Doornkamp, J. P. A. Vogels and R. T. Wegh, Adv. Mater., 2003, 15, 1420.

18 U. A. Hrozhyk, S. V. Serak, N. V. Tabiryan, T. J. White and T. J. Bunning, Opt. Express, 2010, 18, 9651.

19 L. De Sio, T. Placido, S. Serak, R. Comparelli, M. Tamborra, N. Tabiryan, M. L. Curri, R. Bartolino, C. Umeton and T. Bunning, Adv. Opt. Mater., 2013, 1, 899.

20 T. Yoshioka, T. Ogata, T. Nonaka, M. Moritsugu, S.-N. Kim and S. Kurihara, Adv. Mater., 2005, 17, 1226.

21 E. Montbach, N. Venkataraman, A. Khan, I. Shiyanovskaya, T. Schneider, J. W. Doane, L. Green and Q. Li, SID Int. Symp. Dig. Tech. Pap., 2008, 39, 919.

22 S. M. Morris, P. J. W. Hands, S. Findeisen-Tandel, R. H. Cole, T. D. Wilkinson and H. J. Coles, Opt. Express, 2008, 16, 18827.

23 S. Furumi and N. Tamaoki, Adv. Mater., 2010, 22, 886.

24 M. Moirangthem, R. Arts, M. Merkx and A. P. H. J. Schenning, Adv. Funct. Mater., 2016, 26, 1154.

25 D. J. Mulder, A. P. H. J. Schenning and C. W. M. Bastiaansen, J. Mater. Chem. C, 2014, 2, 6695.

26 H. K. Bisoyi and Q. Li, Chem. Rev., 2016, 116, 15089.

27 J. Lu, W. Gu, J. Wei, W. Zhang, Z. Zhang, Y. Yu, N. Zhou and

X. Zhu, J. Mater. Chem. C, 2016, 4, 9576.

28 Y. Wang and Q. Li, Adv. Mater., 2012, 24, 1926.

29 H. K. Bisoyi and Q. Li, Acc. Chem. Res., 2014, 47, 3184.

30 T. J. White, R. L. Bricker, L. V. Natarajan, N. V. Tabiryan, L. Green, Q. Li and T. J. Bunning, Adv. Funct. Mater., 2009, 19, 3484 .

31 Y. Xie, D. Fu, O. Jin, H. Zhang, J. Wei and J. Guo, J. Mater. Chem. C, 2013, 1, 7346.

32 D. Bléger, J. Schwarz, A. M. Brouwer and S. Hecht, J. Am. Chem. Soc., 2012, 134, 20597.

33 L. Qin, W. Gu, J. Wei and Y. Yu, Adv. Mater., 2018, 30, 1704941.

34 H. Huang, T. Orlova, B. Matt and N. Katsonis, Macromol. Rapid Commun., 2017, 39, 1700387.

35 G. Heppke and F. Oestreicher, Z. Naturforsch. A, 1977, 32, 899.

36 K. Akagi, Chem. Rev., 2009, 109, 5354.

37 J. Ma, Y. N. Li, T. White, A. Urbas and Q. Li, Chem. Commun., 2010, 46, 3463. 